\title{
Communication Education: Experiment Class with Old and New Teaching Style Digitalization of Ideas and Work
}

\author{
Pratiwi Cristin Harnita \\ Faculty of Social and Communication Sciences \\ Satya Wacana Christian University \\ Salatiga, Indonesia \\ pratiwi.cristin@yahoo.com
}

\begin{abstract}
We investigated how changing behavior in class related to catch interest. In this study, we see the results of learning related to attitudes based on responses-stimulus theory of attention, understanding and acceptance. At the end of the semester, the result of acceptance is incredible, there is no complaints from all students. Especially in this class experiment (qualitative approaches), digital assignment and paper is given by created a personal blog. Student writing is often seen by their instructor, which can make the assignment not really make them excited. Conversely, persuasive of communication at class without using power point presentation and digitalizing student assignment was related to student motivation inside the classroom and beyond.
\end{abstract}

Keywords-educational communication; learning motivation; stimulus-response; digital assigment

\section{INTRODUCTION}

Intructors interactive teaching style has been positively associated with students' deep and strategic learning strategies [1]. Based on my teaching experience, sometimes the class becomes very stiff and lacks of interest. According to Goetz and Hall, "a lack of student motivation can be a lesson from instructors, expend less energy learning course material" [1]. There are some subjects that are taken by students. Communication Sociology class is observation unit for this experiment. Before the class begins, researchers find a negative response about the class. This class considered difficult by students. "Difficult labels" of the class was a negative perception.

Instructors need to hold student perception that can encourage class motivation. "Instructor can reduce negative outcomes by influencing student motivation, and one way to achieve this goal through the manipulation of their interest" [2]. There should be effort manipulation of interest and motivation of students with persuasive communication skills to be able to change thinking, attitude and behavior. The effectiveness of educational Communication will be success if the message can be delivered to the recipient. Student can comprehending the material subject.

\section{RESEARCH METHODS}

In this experiment, researchers do not see how the "way of communication learning" however how educational communication "changes attitudes" and related to student interest. In this experimental research model, the attention, understanding and acceptance adopted from the stimulus response stimulus theory became the focus of observation. According to Hovland, examining the attitude there are three important variables of attention, understanding, acceptance [3].

There are 141 participant, using a qualitative research with experimental observation method. The research was conducted in Sociology of Communication class in 2017 at Faculty of Social and Communication Science, Universitas Kristen Satya Wacana, Salatiga, Central Java, Indonesia. In this experiment, researchers act as teachers and change the learning system by not using power point presentation and used the internet for every student assignment. The combination of old and new ways is related to stimulate student interest. This study investigated "millennials" respond old teaching model and engage the digital community to assess student task.

\section{RESULT}

The following is a three-month observation.

\section{A. Attention Ability}

There are 14 class meetings. In 1-2 weeks, students learning about subject material with old way learning style. Instructor just doing oral presentation. The purpose using the old way communication for gaining student attention. At week 3 , the teaching method with the main mapping. In weeks 4 - 5 is finding the main idea of journals but only 2 of 141 students are able to find the essence of the reading. At the 6th week students are divided into groups to discuss social communication phenomenon.

Most of the group were able to discover the social interpretation and find the problem. They need to improve their literate ability and logical thinking. In this class, student 
must create main mapping for fact finding and avoiding logical fallacies. In the week 7-8, students make a creative presentation, some of the main presentation of mapping and others in the form of drama. At 9-10 weeks they make observation tasks and write their opinions in the form of articles and published on the internet. Through the portal www.kompasiana.com student writing gets quite interesting response, 4 people writing got trending articles and headlines. At week 11-12 students learned about theory. The student in class $\mathrm{A}$ and $\mathrm{C}$ show more interested with many question and its quite dynamic class. But different situation happened at class B. Negative outcome can be influenced by starting class hours and the atmosphere of a narrow room. At week 13, students are not in the class but making a social experiment video. In the video experiment, the students are excited because they are directly in the community and create a video that aims to changing audience perception and behavior about every single things that should be public's attention. Nowadays people do not really care about their society. This video is uploaded on YouTube. At week 14, student presented their social experiment video. They tried to express their opinion. The discussion was very enthusiastic.

\section{B. Understanding Ability}

The achievement of learning is quite successful but no one has got $\mathrm{A}$ for the subject. The highest score is $\mathrm{AB}$, and the lowest is BC. Assessment is obtained after the calculation of 2 teachers and get added value from the results of public assessment through digital media. There are several indicators of the essay question to see how far students understand the sociological context of communication theoretically and reasonably

- $\quad$ Describe the sociology of communication according to the books? (Question in second week)

Based on the results of the essay, for the first point was found 132 participants answered according to the book and 9 participant cant answered this question.

- Describe your opinion about sociology of communication? (Question at 12th week)

For the second point 120 students answered as expected, 11 almost true answered but lack of data support, and 10 answered wrongly.

It means, student can comprehending subject material.

\section{Reception Ability}

This is secondary data from the Institute of Quality Assurance and Internal Audit (LPMAI) of the university, where students must fill out the questionnaire before taking the next semester schedule. This is rank from Class A (50 participant) for sociology of communication 2017.

Question indicator:

- Clarity about the course at the beginning of the semester

- Clarity about task and evaluation systems
- Systematic Submission of Lectures

- Business lecturer in motivating students

- Clarity of course material

- A fun and refreshing atmosphere created by a lecturer

- Clarity and answer student questions

- The attraction generated by lecturers

- Clarity about any given task

- The way the lecturer stimulates critical thinking

- $\quad$ Lecturer's effort to help understand lectures

- Quality of outside classroom guidance

- Effective use of lecture time in each meeting

- Relevance of duty to course

- Quality of lecturer's corrections / feedback on assignments and tests to students

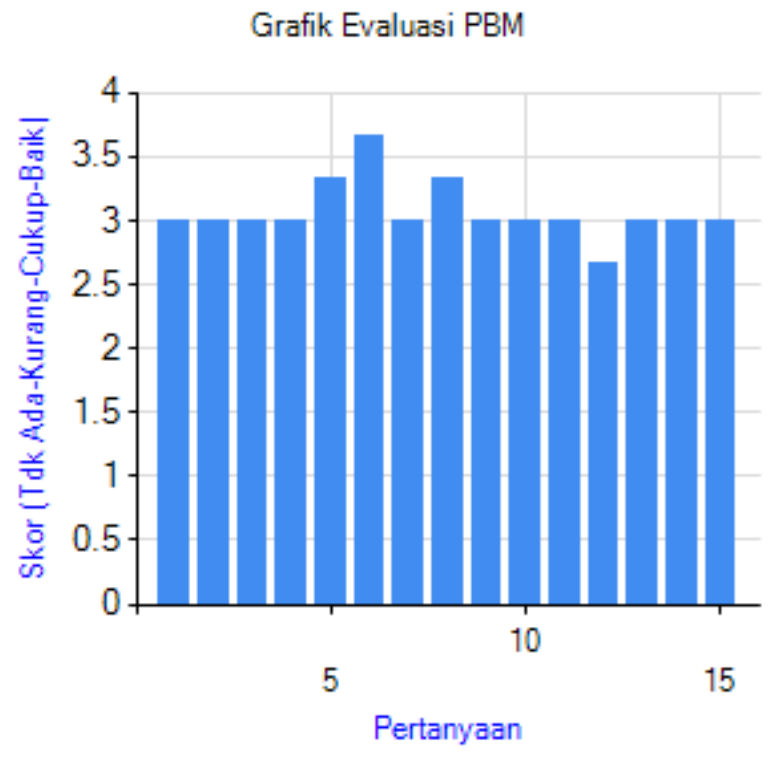

Fig. 1. Evaluation Learning Process (LPMAI, 2017)

Overall, the attention of students in the sociology communication class is very good. Situational factors related to student interest. The results of this experiment show that learning process without power point presentation and show student work in the internet also effective increasing attention, understanding and acceptance in teaching and learning process. This is also reinforced by secondary data from LPMAI survey results seen in score 5 (message clarity), 6 (fun classroom atmosphere), and 8 (class attractiveness) got high scores from students.

People comments when the idea of student ideas is uploaded in the internet. It becomes a stimulus for students ideas and works. In new media theories, such according to McQuail [4],"that new media allows for reciprocity (interactivity) so that recipients can choose, exchange information, reply back and connect with other recipients directly. In addition, the advantages of this new media has the flexibility of form, content and usage."

"Kami semangat kak mengerjakan tugas video eksperimennya - we really excited making the social 
experiment video" Gery said one of the students who got the highest score,"saya rasa saya layak dapat nilai B - I thing B is okay... " Madeline said accept the value given. Usually, open forum tradition is often in the faculty when at beginning of the new semester, where students will submit various complaints in learning last semester. The is not complaints or requests for improvement of value for class. The results of learning achievement is well received and the students are able to measure their self ability despite no one get A scores.

\section{The Millennia's Generation and Digitized Education}

Building interest in learning is important because it is an important part of human motivation. Hidi in Bolkan [1, p. 269] says "Interest is what the teacher needs in his class is finding a variety of learning models that right." Each generation has different characteristics. Currently education also needs to adjust. The demand for paperless, even now the book not only be a reference even students can find fresh ideas from the internet. A few years ago, the source of the internet was still questionable to be a data supporter of learning, but many appropriate data digitized on e-books, e-journals, e-papers are easy to access and tagged. The world is changing by technologies. The digitalization of the world of education make learning process more interesting.

In this experimental class, instructors do not use power point to hold class attention. Students actively record and increase the literacy of the book. In this study, combining old and new method teaching makes students more sensitive to the material discussed and able to more objectively accept the assessment results. In contrast to other classes that use the help of power points in learning and still working on scientific papers in print. "Oleh karena itu pengajar harus mahir dalam berkomunikasi lisan dan istruksional karena akan menentukan keberhasilan anak didiknya belajar" (Therefore, teachers must be proficient in oral and istruksional communication because it will determine the success of their students learn [5].).

This class requires students to be more sensitive to the society. Students are stimulated to be able to find the community problem and create the solution. This is a challenge because students are not only demanding theoretically but also relating it in social life. Therefore, to persuade students to think critically but also have an interest in the classroom. It is necessary to make every topic related with their life experience. Personal interest is controls variable in this study. "From an educational point of view, situational interest is the real topic of concern as teachers have no influence over student incoming personal interest" [6]. Not only that, the world of college in the next few years will receive a wave of their $Z$ generation (born 2005) which since birth has tasted the ease of technology and grow in the information society. Therefore, there needs to be further research to find the right teaching pattern for students in the digital age.

Especially in this class experiment, digital assignment and paper is given. Their making blog. Student writing is often seen by their instructor, which can make the assignment not really make them excited. The dynamic situation between author and audience can make student see the real value of the subject material. Student can learning about integrative learning. They learning about academic and social experience. When student writing for blogs, they can interact digitally. Finding a new experience in a digital society. Blog can make student feels writing formal assignment and freedom to experiment their ideas and argument.

\section{E. Effect of Motivation on Learning Styles}

According Bain (2004 pages 40-41) from the "What The Best College Teachers Do" said about the effect of motivation on learning styles. "Deep learners respond well to the challenge of mastering a difficult and complex subject. These are intrinsically motivated students who are often a joy teach!. Strategic Learners are motivated primarily by rewards. They react well to competition and the opportunity to best others. They often make good grades but wont engage deeply with a subject unless there is a clear reward for doing so. They are sometimes called "bulimic learners by avoiding appeals to competition, appeal to their intrinsic interest in the subject at hand. Design your assignment (test, papers, projects, etc) so that deep engagement with the subject is necessary for success on the assignment. Do so by requiring students to apply, synthesize, or evaluate material instead of merely comprehending or memorizing material. Surface Learners are often motivated by a desire to avoid failure. They typically avoid deep learning because it they see it as inherently risky behavior. They will often do what it takes to pass an exam or course, but they won't choose to go beyond the minimum required for fear of failure. Handle surface learner by helping then gain confidence." 1

\section{CONCLUSION AND CONTRIBUTION}

Usually teachers want students to be more eager to learn their subject matter. When students come to class are often influenced by the interests and perceptions that have been formed. Students needs to be helped to improving their learning motivation. Therefore a positive relationship needs to be built from the beginning of class. In the learning process there needs to be a common goal and understanding of class achievement. Learning achievement is not merely about the scores. Actually, learning process to be more fun and make the students understand the topic.

According to response-stimulus theory is divided into 3 steps: attention, understanding and reception. It can be a guideline for teachers to create a strategy for generating a response to the class. Teachers need to be more creative to managing the class. If the old way is too tired to do, then we need to make another different teaching style. Combining old and new teaching style for innovation and generating student interest. Drawing attention is the first step is necessary thing.

1 Bain from the "What The Best College Teachers Do" https://cft.vanderbilt.edu/guides-sub-pages/motivatingstudents/ 
In persuasive communication, people will easily say "yes" when they like someone. Similarly, a teacher, should be able to make the students agree and gladly not because of tension.

Often teachers only perform their duties as teachers so that things related to the motivation of students beyond the reach and thought. There is an assumption that "teachers only share knowledge instead of entertaining" but in reality many classes become so lackluster. The students, bowed lethargic, often looking at the clock, talking to each other and not paying attention to the teacher. Of course, lack of interest will be influence students to comprehend the topics. The power of educational communication is to convey a message to be understood and understood by the students.

In terms of improving understanding, teacher can successfully hold student attention to gaining curios mind about the topics. You will get positive feedback which is dynamic dialogue when discussing, and questions arise related to the topic in the classroom. So, scores and grade is not really necessary. Process to comprehend topics is necessary and how teacher does to stimulates their class with an innovative strategy. An educator also has a teaching plan that can be a guide for students to follow the lesson. The beginning and end of class impression is important. Teachers should emphasize the topic to be understood and applied to their lives. It is useless if a theory is incapable of helping their lives.
After attention and understanding, then the most recent is the response to the teaching we have done that is acceptance. We get requests and protests about the end of class. Dissatisfaction with learning may come from a variety of factors. A positive response appears characterized by a good acceptance of learning outcomes.

\section{REFERENCES}

[1] S. Bolkan, and D. J. Griffin, "Catch and Hold : Instructional Interventions and their Differential Impact on Student Interest, Attention and Autinomous Motivation,” Commun. Educ., vol. 67, pp. 269-286, 2018. DOI: 10/1080/03634523.2018.1465193.

[2] K. Weber, "The Relationship Of Interest to Internal And External Motivation,” Commun. Res. Reports, vol. 20, pp. 376-383, 2003. DOI : 10.1080/08824090309388837.

[3] O. U. Effendy, Ilmu Komunikasi Teori dan Praktek [Communication Science, Theory and Practice]. Bandung: PT. Remaja Rosdakarya, 2003.

[4] D. McQuail, Teori Komunikasi Massa [Mass Communication Theory], 6th ed., Jakarta: Salemba Humanika, 2011.

[5] Suparno, "Kemahiran Berkomunikasi Lisan Dalam Konteks Instruksional Guru Sekolah Dasar [Oral Communication Proficiency in The Instructional Context of Elementary School Teacher],” Jurn. Ilmu Pend., vol. 6, no. 1, pp. 51-60, 1999.

[6] M. Mitchell, "Situasional Interest : Its Multifaceted Structure in The Secondary School Mathematics Classrom,” J. of Education. Psychol., vol. 85, pp. 424-436, 1993. DOI : 10.1037/0022-0663.85.3.424. 